\title{
Using E-Learning Technologies in Teaching and Learning Process
}

\author{
Lina Lafta Jassim ${ }^{1 *}$ \\ ${ }^{I}$ College of Art, University of ThiQar, Iraq \\ *e-mail: lina.art@utq.edu.iq
}

\begin{abstract}
The Information and Communication Technologies (ICTs) use has become a major driving force in transforming education worldwide. Similarly, in the last ten years, the usage of Information and Communication Technologies and elearning approach in Iraq has increased. Whereas, the latest educational policy of the Government of Iraq has focused on using Information and Communication Technologies and e-learning in schools and universities. The national professional standards for teachers have also suggested teachers to integrate Information and Communication Technologies in their classrooms and develop eLearning Platforms for teaching and learning processes. However, in this study the effectiveness of Information and Communication and e-learning Technologies integration in teaching and learning has been assessed. The context selected for this research study is University of Baghdad Iraq. The research gap, which has been founded through the extensive literature review indicated that most of the students are not able to utilize Information and Communication Technologies effectively. The first objective of this study is to enable students to gain wider range of knowledge and make them enable to access internet for developing a global outlook. Moreover, the second objective of this study is to develop students' capabilities of processing information more effectively and efficiently for teaching and learning.
\end{abstract}

Keywords:

E-Learning Technologies; Interactive Learning; Educational Technology; Empirical Study.

\begin{abstract}
ABSTRAK
Penggunaan Teknologi Informasi dan Komunikasi (TIK) telah menjadi kekuatan pendorong utama dalam mengubah pendidikan di seluruh dunia. Demikian pula, dalam sepuluh tahun terakhir, penggunaan Teknologi Informasi dan Komunikasi dan pendekatan e-learning di Irak meningkat. Padahal, kebijakan pendidikan terbaru Pemerintah Irak lebih menitikberatkan pada penggunaan Teknologi Informasi dan Komunikasi serta e-learning di sekolah dan universitas. Standar profesional nasional untuk guru juga menyarankan guru untuk mengintegrasikan Teknologi Informasi dan Komunikasi di ruang kelas mereka dan mengembangkan Platform e-Learning untuk proses belajar mengajar. Namun, dalam studi ini
\end{abstract}


efektivitas integrasi Teknologi Informasi dan Komunikasi dan e-learning dalam proses belajar mengajar telah dinilai. Konteks yang dipilih untuk studi penelitian ini adalah Universitas Baghdad Irak. Kesenjangan penelitian, yang ditemukan melalui tinjauan pustaka ekstensif menunjukkan bahwa sebagian besar siswa tidak dapat memanfaatkan Teknologi Informasi dan Komunikasi secara efektif. Tujuan pertama dari studi ini adalah untuk memungkinkan siswa memperoleh pengetahuan yang lebih luas dan memungkinkan mereka mengakses internet untuk mengembangkan pandangan global. Selain itu, tujuan kedua dari studi ini adalah untuk mengembangkan kemampuan siswa dalam memproses informasi secara lebih efektif dan efisien untuk proses belajar mengajar.

\section{Kata kunci:}

Teknologi E-learning; Pembelajaran Interaktif; Teknologi Pendidikan; Studi Empiris.

\section{Introduction}

ICTs refers to technologies and communication of information by electronic equipment especially computer for creating, storing, analyzing and sending information. In Iraq society, teaching is considered as a most complicated profession where ICT takes deep roots to attain a great source of information. ICT ensures a long-lasting effect on learning through text, graphics, animation or audio and videos. In addition, it develops positive groups and social interaction and enhances interpersonal and intrapersonal skills of learners.

Information communication technology (ICT) pertains to the use of computer-based communication that involves classroom and e-learning instructional methods. Moreover, ICT can fulfill the aim by expanding the rise of quality, accessibility and cost-efficiency of the delivery of instruction to students, it gives learners benefits to face the challenges of globalization (John, 2015 ; Jassim ,2016). Furthermore, ICT plays a substantial role to change enormous aspects of human endeavor's and it let great influences on numerous fields just like medicine, tourism, law, banking, business, and engineering. Therefore, integration is not based on a single step it pursues constant steps that complete support teaching-learning information resources.

Through ICT, learners can easily access online course material at any time at any place. Now, by utilizing ICT learning is no more based upon printed materials. Huge resources are available on the internet through which knowledge can be progressed with huge variety of presentation topics, videos, audios, graphs and graphs and so forth. Furthermore, Current research stated that ICT helps to transform from the teacher-centered environment into a learner-centered setting(Sánchez \& Alemán, 2011 \& Jassim ,2015).Subsequently, ICT classroom learners are actively engaged, teachers make them authorized to make decisions, plans and solve their problems (Fu, 2013) Therefore, ICT provides great assistance to instructors and learners to gain maximum possible knowledge in the educational area .Likewise, revealed that ICT left profound impacts on the education system and it is observed that ICT enables great learning potential and interactive learning environment in countries which integrated ICT(Hennessy, Harrison, \& Wamakote, 2010). Some researchers stated that ICT expands the significance of education and it prospers effective pedagogies to provide the effective understanding and enhance communication in learning. Including (Bingimlas, 2009) many 
other researchers acknowledged that ICT expands learner's knowledge. Thus, ICT is computerbased and should integrate into education which can greatly impact student accomplishment.

In early 1990 computer technology initiated in the classroom. Expectations regarding ICT become high that it would change the shape of education system. It was estimated that ICT ultimately replaced textbooks through eLearning. Though the use of ICT is greatly supported by educational policymakers (Wong \& $\mathrm{Li}, 2008$ ). Integration of ICT is observed to be more important to expand the effectiveness of teaching and learning methods. As Technology unfolds an important role in our daily lives, it can also perform a significant role in the process of education (Hew \& Brush, 2007). Adapting great levels of ICT in various schools, it has been observed that it does not bring any change in practicing teaching and learning(Coll, Mauri, \& Onrubia, 2009). Many researchers recommended that teachers should be given appropriate training for the effective integration of technology and e-learning in making teaching and learning method more refine. If they are aware of proper utilization of ICT certainly, they will face problems to plan teaching activities and projects where ICT need are greatly observed.

This study based to determine integration of ICT and e-learning at higher educational institutions in Iraq. It is known that all learners are not effectively implementing ICTs in their learning; the reason is very considerable investments to the ICT integration in the learning. ICT indicators' in education have aim to enhance educational outcomes and improve the quality effectiveness of learners (Wong \& Li, 2008). Educators are not efficiently using computers as they should suffer with the emergence of rapidly changing technologies, it should keep in mind that learners must have to know and learn new skills and practices new knowledge (Wells \& Lewis, 2006).

In addition to it, many countries are investing billions of dollars to equip the schools with modern computers and telecommunication networks. Furthermore some Studies shows that not all teachers are fully aware of the numerous benefits of ICT and how to take advantage of them in the classroom some teachers may have positive attitudes towards integrating ICT in the classroom. (Hew \& Brush, 2007 ; Jassim \& D Zakiria,2019). Further, ICT speculated as one of the great economic advancement pillars to achieve the nationwide competitive goal. It can broaden the betterment in human life through learning and progressing education. Therefore, the purpose of this study is to observe the effectiveness of ICT in teaching and learning and its impacts on students learning, gaining knowledge and prepares students to achieve greater competency on their subject matter.

ICT associated with communication technology. In today's life, technology gets advancement day by day and the internet is supposed to play a most vital role. It contributes and provides incredible benefits in the field of education. It is an inappropriate way to keep students stuck around the four walls of the class cabin. Teaching is considered as an art and that art requires understanding various developmental features of pupils at their different stages. ICT enables to perform great advantages for the teacher to achieve quick information on the learner work and performance. Modern technologies improve the quality of teaching-learning. It has become a valuable part of the daily routine work. Technologies expand the setting of learning and enhance instruction productivity. Through computer technology notes, books, publications, magazines can be easily 
digitalized. Thus, it provides great favors to teachers and learners in extending knowledge. ICT stimulate skill construction and fascinating lifelong learning. Through the internet, students can discover great information relevant to their subjects that brings forth the performance of the student on the basis of teacher expectations.

The goal of ICT integration in the teaching and learning process reveals the vision and mission of the Government. The aims and objectives of this research are:

1. To find out the extent of ICT and e-learning use in the teaching and learning in University of Baghdad Iraq.

2. To enable students to acquire wider range of knowledge for developing a global outlook by using ICTs and e-learning.

3. To identify students' capabilities of processing information more effectively for teaching and learning by using ICTs and e-learning.

To achieve the research objectives these are research questions:

1. To what extent ICT and e-learning used in the teaching and learning process in a public university of Iraq?

2. What motivates students to acquire wider range of knowledge by using internet?

3. What are the student's capabilities of processing information more effectively by using ICTs and e-learning?

Keeping in the view the research questions, theses following hypothesis are formulated:

H1: The effective ICTs and e-learning integration has a significant impact in teaching and learning process in a public university of Iraq.

The motivation of students to gain more knowledge can be enhanced through the use of ICTs and elearning in teaching and learning process.

The capabilities of students processing information can be made effective by the integration of ICTs and e-learning in Teaching and learning.

\section{Method}

This section describes procedures that are followed in conducting this study. It consists of the descriptions of the research design, population, location the study sampling. Also, the data collection and analyzing techniques. This research is followed by a quantitative methodology by following descriptive (Survey) research design describes the survey research as a study on different number of populations, with the help of chosen selected population. By using quantitative approach researchers able to know the reliability of the tool in the context of Iraq. According to (Creswell ) quantitative research is known as the process of collecting, analyzing, interpreting, and writing the results of a study.

This study was carried out in the Sindh Iraq.it was selected purposively. Because, it was easy for researchers to access the selected university and collect the required data about their study. For this study the targeted population was the students and teachers of University of Baghdad. As the 
teachers are real implementers of the designed curriculum of universities. Therefore, they play vital role in the process of teaching and learning. Similarly, students learn from that environment and can give important feedback about the teaching and learning process. The total participants for this research were 80 students and 20 teachers from University of Baghdad. The questionnaires were randomly given to all respondents. So, for respondents that take part in the study were from the business, English and computer science departments.

The filled questionnaire rate is the same as the sample selected for this study. The questionnaires were administered to a sample of a total of 100 participants. Out of that, 80 were students and 20 teachers. All participants filled and returned the questionnaire to the researchers. Table 1 shows a summary of the filled questionnaire rate.

Table 1. Filled Questionnaire Rate

\begin{tabular}{cccc}
\hline Respondents & Sampled & $\begin{array}{c}\text { Filled and } \\
\text { Returned }\end{array}$ & Percentage \\
\hline Students & 80 & 80 & $80 \%$ \\
Teachers & 20 & 20 & $20 \%$ \\
\hline Total & 100 & 100 & $100 \%$ \\
\hline
\end{tabular}

Regading to Gender Distribution, the participants were asked to state their gender, both Tables 2 and 3 shows the summary of the findings related to gender about students and teachers respectively.

Table 2. Student's Gender

\begin{tabular}{lcc}
\hline \multicolumn{1}{c}{ Gender } & Frequency & Percentage \\
\hline Female & 30 & $37.5 \%$ \\
Male & 50 & $62.5 \%$ \\
\hline Total & 80 & $100 \%$ \\
\hline
\end{tabular}

Table 3. Teacher's Gender

\begin{tabular}{lcc}
\hline \multicolumn{1}{c}{ Gender } & Frequency & Percentage \\
\hline Female & 5 & $25 \%$ \\
Male & 15 & $75 \%$ \\
\hline Total & 20 & $100 \%$ \\
\hline
\end{tabular}

The participants were asked to mention their department in questionnaire, Table 4 and 5 highlights the summary of findings about student's department and area of specialization of teachers respectively:

Table 4. Department of Students

\begin{tabular}{lcc}
\hline \multicolumn{1}{c}{ Department } & Frequency & Percentage \\
\hline Business & 20 & $25 \%$ \\
Administration & 36 & $45 \%$ \\
English & 24 & $30 \%$ \\
Computer Science & \\
\hline
\end{tabular}


Table 5. Area of specialization of teachers

\begin{tabular}{lcc}
\hline \multicolumn{1}{c}{ Area of Specialization } & Frequency & Percentage \\
\hline Business & 8 & $40 \%$ \\
Administration & 5 & $25 \%$ \\
English & 7 & $35 \%$ \\
Computer Science & \\
\hline
\end{tabular}

The participants of this study were asked to state their age in years. Table 6 describes a summary of the findings of teachers age, and Table 7 shows the finding of teachers age.

Table 6. Teacher's Age

\begin{tabular}{cc}
\hline Age & Percentage \\
\hline $18-25$ & $20 \%$ \\
$25-30$ & $50 \%$ \\
$30-35$ & $30 \%$ \\
More than 35 & $0 \%$ \\
\hline
\end{tabular}

Table 7. Students Age in Years

\begin{tabular}{cc}
\hline Age & Percentage \\
\hline $18-25$ & $100 \%$ \\
$25-30$ & $0 \%$ \\
$30-35$ & $0 \%$ \\
More than 35 & $0 \%$ \\
\hline
\end{tabular}

The teachers who participated in this study were asked to mention their teaching experience in years, Table 8 gives the summary of finding.

Table 8. Teacher's Teaching Experience in years

\begin{tabular}{cc}
\hline Teaching Experience less than 5 years & Teaching Experience more than 5 years \\
\hline $65 \%$ & $35 \%$ \\
\hline
\end{tabular}

Two survey questionnaires are used for data collection. One with total 22 items and other consists of 10 items. In that all participants were asked to read the given statements that were provided in the questionnaire. They were instructed to choose the answers on the bases of Likert scale. That ranged from the $5=$ Strongly Disagree, $4=$ Disagree, $3=$ Neutral $2=$ Agree and $1=$ Strongly Agree. Both the questionnaires were consisted of 2 sections. A section is about the demographic information of participants. That consists of Gender, Age, Department and Teaching experiences. Furthermore, the other part in the questionnaire are consists on the students and teachers' perceptions about the effective integration of ICTs in teaching and learning process. The questionnaire that were used for data are adopted and changed from the original ones that are designed by the (Guven, 2008). Because these are considered best suitable for this research. Similarly provided items in questionnaires provides the answers to research question

The researchers modified the questionnaires before giving it to targeted population. By following the Morgan's rules for sample selection, then, each researcher takes up 40 and 40 questionnaires respectively that made a total of 80 questionnaires being distributed to all respondents. And also 20 questionnaires filled from teachers. The data were collected in the 2 
weeks. The total 30 minutes were given to the respondents in order to fill the questionnaires. And then return back that to researchers for the analysis of data. That's helped the researchers to find out the findings of that study.

The data that was collected from the participants were analyzed by using (SPSS) Statistical package for social science version 22.0. In this analyzes both the descriptive and inferential analysis included. In addition to this researcher used the descriptive analysis to know the frequency and percentage of demographic information of the population. Furthermore, it used to show the mean, standard deviation, percentage and frequency to know the effectiveness of ICTs integration in the teaching and learning process at a public university of Iraq.

\section{Result and Discussion}

The filled questionnaire rate is same as the sample selected for this study. The questionnaires were administered to a sample of total 100 participants. Out of that 80 were students and 20 teachers. All participants filled and returned the questionnaire to the researchers. The reliability of a questionnaire 1 about the perception of students about the effective integration of ICTs is shown in table 4.9 it highlights that Cronbach's Alpha is about 0.7. As the matter of fact, the alpha coefficient 0.7 is considered to be appropriate. Similarly, the reliability of a questionnaire 2 about the perception of teacher about the effective integration of ICTs is above in table 4.10 it highlights that Cronbach's Alpha is about 0.5. As the alpha coefficient 0.7 is considered to be significant. But it shows less significant.

Table 9. Statistical Findings

\begin{tabular}{llcc}
\hline Code & $\mathrm{N}$ & Mean & Std. Deviation \\
\hline SR1 & 80 & 1.5375 & 0.57244 \\
SR2 & 80 & 1.7625 & 0.83049 \\
SR3 & 80 & 2.2000 & 0.95996 \\
SR4 & 80 & 2.0375 & 1.03659 \\
SR5 & 80 & 2.0875 & 1.04571 \\
SR6 & 80 & 2.4250 & 1.01601 \\
SR7 & 80 & 2.2500 & 1.10808 \\
SR8 & 80 & 2.5375 & 1.06668 \\
SR9 & 80 & 1.8875 & 0.94123 \\
SR10 & 80 & 1.8875 & 1.06728 \\
TR1 & 20 & 1.5000 & 0.51299 \\
TR2 & 20 & 1.4500 & 0.68633 \\
TR3 & 20 & 1.6500 & 0.74516 \\
\hline
\end{tabular}

Finding highlights that the highest mean of 2.5 that students are agreed that ICTs Kept great influence on their behavior. In the smallest mean of 1.53 , it has recorded that students did not believe that ICT is helpful to bring creativity and innovative ideas which assume that they are not satisfied with technologies assistance and could not rely on ICTs to bring more creativity and fresh insights. However, it has been asserted through the smaller mean of 1.88, students perceived that ICTs play an important role to communicate the ideas effectively. Moreover, throughout outcomes 
of study, it is observed, the majority of students believed that ICT played significant role in an enhancement of knowledge with mean of 2.4, it provides great assistance to make effective learning with the approximate mean of 2.0, Pupils considered that with sources of technology they comprehend their ambiguous concepts and it is useful to develop confidence level with 2.03 mean.

Finding highlights that the teacher assumed, the use of ICTs is wastage of time with an approximate highest mean of 4.15. However, they perceived that ICTs is an easier way of teaching with the lowest mean of I.4. In addition, it is observed through collecting data that teachers favored the use of ICTS and they felt that ICTs play an effective role in learning with a similar mean of 1.6. Moreover, it has been observed that teachers feel that they don't have enough time for using ICT but still they feel that they learn great new things through the help of ICT and feel comfortable in use of technologies with the same mean of 2.0. Furthermore, it has been estimated with a mean of 2.90 that teachers felt a lack of support from managed for effective ICTS integration in the campus. Teachers believed that ICTs enhance the quality of teaching and helpful for preparing teaching resources materials with the exact same mean of 1.85. Subsequently, they speculated that ICT's focus to fulfill the student's demands of learning with a mean of 2.5 .

\section{Conclusions}

According to the study of the effectiveness of ICT and e-learning integration in teaching and learning found that there is a lack of support and management which didn't encourage the integration of ICT in teaching and learning. This study suggested that the teachers are satisfied with the effectiveness of using ICT in their own learning perspective but feel slightly reluctant to implement ICT in a classroom atmosphere. This study also finds out that the majority of teachers supposed that it is not that much productive in the classroom and they considered that it is the toughest way to engage students by implementing ICTs in the classroom. Reason could be lack of providing trainings on effectiveness of ICT from management and no arrangement for ICT implementation in classroom. In spite of this, teachers and students favor the statement that it, greatly helpful for student learning and mainly focused on student need-based, it develops enthusiasm in learning and students share their understandings, beliefs effectively. Through this study, teacher and students are seemed to be satisfied that ICT plays significant roles to develop proficiency of knowledge.

The aim of this study was to find out that to what extent ICTs and e-learning is integrated in the teaching and learning in University of Baghdad Iraq. This study also identified the student's capabilities of processing information more effectively for teaching and learning by using ICTs. Firstly, the findings suggest that questionnaires are reliable in the context of Iraq. In conclusion, to make effective implementation of ICTs it is to make sure that availability of ICTs is presents and either teachers or students are able to use it effectively. However, the availability of ICTs facilities and support from management was not found to be statistically significant. In addition to this students and teachers must be provide with the equipment's and make them literate about the ICTs and e-learning knowledge and skills. It helps the teachers to improve the teaching methods to promote the effective learning also to meet the demands of the 21 st teaching and learning skills. 


\section{References}

Bingimlas, K. A. (2009). Barriers to the successful integration of ICT in teaching and learning environments: A review of the literature. Eurasia journal of mathematics, science \& technology education, 5(3).

Coll, C., Mauri, T., \& Onrubia, J. (2009). Towards modeling of the teaching-learning mediated by ICT. Educational Technology, 145-161.

Dikko, M. (2016). Establishing construct validity and reliability: Pilot testing of a qualitative interview for research in Takaful (Islamic insurance). The Qualitative Report, 21(3), 521528.

Fu, J. (2013). Complexity of ICT in education: A critical literature review and its implications. International Journal of education and Development using ICT, 9(1), 112-125.

Hennessy, S., Harrison, D., \& Wamakote, L. (2010). Teacher factors influencing classroom use of ICT in Sub-Saharan Africa. Itupale online journal of African studies, 2(1), 39-54.

Hew, K. F., \& Brush, T. (2007). Integrating technology into K-12 teaching and learning: Current knowledge gaps and recommendations for future research. Educational technology research and development, 55(3), 223-252.

Jassim, L. L.(2015). Analysis of Semantic Errors in Iraqi EFL Learners' writings. The Journal of University of ThiQar,11(4):184-162

Jassim, L. L.(2016). Investigation of Sequential Progression Topics in Iraqi EFL Students' Writing, The Journal of University of ThiQar, 10(3):47-63

Jassim, L. L., \& Dzakiria, H.(2019). The Effect of Utilizing Mobile on Developing English Writing Skill. Opción,(34),(19).(2128-21437.

John, S. P. (2015). The integration of information technology in higher education: A study of faculty's attitude towards IT adoption in the teaching process. Contaduría y Administración, 60, 230-252.

Jung, S.-H. (2006). The use of ICT in learning English as an international language.

Sánchez, J. J. C., \& Alemán, E. C. (2011). Teachers' opinion survey on the use of ICT tools to support attendance-based teaching. Computers \& Education, 56(3), 911-915.

Wells, J., \& Lewis, L. (2006). Internet Access in US Public Schools and Classrooms: 1994-2005.

Highlights. NCES 2007-020. National Center for Education Statistics.

Wong, E. M., \& Li, S. (2008). Framing ICT implementation in a context of educational change: A multilevel analysis. School effectiveness and school improvement, 19(1), 99-120. 